https://doi.org/10.52240/1857-2367.2020.2(21).37

\title{
IARBA DE FIER (SIDERITIS SCARDICA GRISEB ȘI S. TAURICA STEPHAN) ÎN COLECȚIA DE PLANTE AROMATICE ȘI MEDICINALE A IGFPP
}

\author{
Lilia CHISNICEAN \\ Institutul de Genetică, Fiziologie și Protecție a Plantelor, \\ Chișinău, Republica Moldova
}

\begin{abstract}
The article contains information on the identification of propagation methods with real possibilities for the cultivation of the species Sideritis scardica and S. taurica, as spice, aromatic and medicinal plants, under the local climatic and soil conditions.
\end{abstract}

Key words: Sideritis scardica, S. taurica, introduction, propagation, medicinal plant, aromatic plant.

Printre speciile nou introduse sunt și două specii Sideritis scardica Griseb. și S. taurica Steph. ex Willd. ale genului Sideritis, din familia Lamiaceae, herba cărora este promovată activ și vândută în calitate de ceai neobișnuit, în toate stațiunile balneare și turistice din Turcia, Grecia, Macedonia, Bulgaria [1, 2]. În țările de origine, speciile sunt cultivate, de regulă, în rocariu și alpininariu, în calitate de plantă ornamentală, medicinală și aromatică [3]. Frunzele, tulpinile și florile speciilor de Sideritis studiate conțin 0,003-0,006\% ulei esențial, iridoide: harpagide, 8-acetilgarpagide, flavonoide. Uleiul gras de $29-30 \%$ a fost găsit în semințe în compoziția cărora mai pot fi identificați acizi (palmitic, stearic, oleic, linoleic, linolenic), vitaminele C și E, minerale [4]. Ambele specii în medicina populară din țările de origine, sunt considerate un imunomodulator natural foarte eficient. Herba farmaceutică a celor două specii studiate are proprietăți hipotensive, antifebrile, diuretice, favorizează cicatrizarea rănilor, ajută la tratamentul tumorilor. Uleiul volatil prezintă activitate antibacteriană, antiprotozoică și proprietăți repelente $[5,6]$. Sunt specii melifere, iar partea aeriană a plantei este utilizată ca condiment, frunzele și inflorescențele - în calitate de ceai cu note proaspete, lămâioase. A fost îniţiat un studiu cu scopul introducerii acestor specii valoroase, ambele, manifestându-se ca plante erbacee în condițiile climatice și de sol locale. Rădăcinile speciilor luate în studiu, având un pivot lemnos, pătrund adânc în sol. Frunzele bazale au dimensiuni mari, iar cele caulinare mai mici, scurt pețiolate, alungit-ovale, întregi. Florile sunt mici, galben-pal, cu nuanțe murdare, cu bractee de culoare verde-deschis, foarte delicate, amplasate în inflorescențe mari, cu verticile false.

Speciile au fost multiplicate prin răsad obținut din semințe, semănate pe un substrat special în palete de plastic și vegetativ, prin înrădăcinarea butașilor vegetativi. Ambele specii - Sideritis scardica și $S$. taurica, se multiplică bine atât prin răsad cât și vegetativ, rata de îndrădăcinare în teren deschisl fiind de $87-90 \%$, formând rădăcini puternice și sănătoase, care pătrund rapid în sol. Deoarece planta are un miros plăcut și multe beneficii medicinale, colectarea frunzelor şi inflorescențelor pentru ceai se efectuează în timpul verii, colectând nu mai mult de o treime din masa vegetativă a plantei, de la începutul până la înflorirea în masă.

Ca rezultat al cercetărilor efectuate au fost identificate metodele de multiplicare, 
care crează posibilități reale de introducere în cultură a speciilor Sideritis scardica și $S$. taurica ca plante condimentare, aromatice și medicinale.

\section{BIBLIOGRAFIE}

1. Lindqvist Ch., Albert V. A. Origin of the Hawaiian endemic mints within North American Stachys (Lamiaceae), 2002. - American Journal of Botany 89(10):1709-1724. Sideritis (англ.). The Plant List. Version 1.1. 2013).

2. González-Burgos E., Carretero M. E., Gómez-Serranillos M. P. Sideritis spp.: Uses, chemical composition and pharmacological activities-A review. Review Article Journal of Ethnopharmacology. Vol. 135, Issue 2, 17 May 2011, P. 209-225

3. Юзепчук C. В. Род 1250. Железница - Sideritis L.//Флора СССР в 30 т./ начато при рук. и под гл. ред. В. Л. Комарова.-М.; Л. Изд-во АН СССР, 1954.- Т. 20 с. 253-273.-с.

4. Iliayana Yaneva1, Valentin Balabanski. History of The Uses of Pirin Mountain Tea (Sideritis scardica Griseb) In Bulgaria. 2013. Bulgarian Journal of Public Heal 56 Th Vol.5 № 1

5. Milka Todorova, Antoaneta Trendafilova. Sideritis scardica Griseb., anendemic species of Balkan peninsula: Traditional uses, cultivation, chemical composition, biological activity. Journal of Ethnopharmacology 152, 2014, 256-265.

6. Koedam, A. Volatile oil composition of Greek mountain tea (Sideritis spp.). J. Sci. Food Agric., 1986. 36, 681-684. 